\title{
Using spatial and behavioral data to evaluate the seasonal bycatch risk of diamondback terrapins Malaclemys terrapin in crab pots
}

\author{
Leigh Anne Harden*, Amanda Southwood Williard
}

Department of Biology and Marine Biology, University of North Carolina Wilmington, 601 S. College Rd., Wilmington, North Carolina 28403, USA

\begin{abstract}
Mortality of marine vertebrates due to incidental entanglement in fishing gear is of global concern. Trends in diamondback terrapin Malaclemys terrapin abundance and demography suggest that bycatch mortality associated with the blue crab Callinectes sapidus fishery may be contributing to population declines and demographic shifts of this estuarine turtle. Designing effective regulations to minimize terrapin-crabbing interaction requires information on the spatial ecology and seasonal behavior of terrapins. Our goals for this study were (1) to identify spatial and temporal patterns in the distribution of terrapins and crab pots and (2) to determine bycatch risk based on seasonal shifts in terrapin behavior and the degree of overlap between terrapins and crab pots. We documented crab pot locations and monitored the movements and activity patterns of 29 terrapins via radio telemetry in southeastern North Carolina from June 2008 to May 2009. To assess spatial overlap and resulting bycatch risk (BR), we calculated seasonal distributions and densities of crab pots and terrapins and incorporated them into a spatial overlap index model (SOI) modified to include the seasonal aquatic behavior of terrapins. Spatial overlap is greatest in warm months when terrapins are swimming in the same shallow, near-shore habitat as blue crabs. When the seasonal and semi-aquatic behavior of terrapins is incorporated into the spatial model, BR is reduced. This behaviorally modified SOI model may be applied to other geographic areas to identify areas and times of bycatch risk between fisheries and non-target species.
\end{abstract}

KEY WORDS: Malaclemys terrapin · Blue crab fishery · Spatial overlap $\cdot$ Bycatch risk $\cdot$ Behavior · Radio telemetry

\section{INTRODUCTION}

Mortality due to incidental capture of non-target species in fishing gear (i.e. bycatch) is of global concern and has been studied in numerous long-lived, pelagic vertebrates, such as sharks, marine mammals, seabirds, and sea turtles (Cox 2003, Sims et al. 2008, Lewison et al. 2009, McClellan et al. 2009). Research on the interactions between estuarine diamondback terrapins Malaclemys terrapin and the blue crab fishery indicates that bycatch mortality due to entrapment in coastal crabbing gear may have a substantial impact on smaller coastal vertebrate populations as well (see Roosenburg 2004 for a list of studies; Dorcas et al. 2007, Rook et al. 2010, Wolak et al. 2010). Diamondback terrapins inhabit marshes and estuaries along the east and Gulf coasts of North America, which are habitats heavily fished for Atlantic blue crabs Callinectes sapidus (Bishop 1983, Seigel \& Gibbons 1995, Roosenburg et al. 1997, Hart \& Crowder 2011). Trends in terrapin abundance and demography observed in long-term studies in South Carolina (Dorcas et al. 2007) and Maryland (Roosenburg et al. 1997) suggest that bycatch mortality of ter- 
rapins from commercial and recreational crab pots may be contributing to shifts in the structure and status of terrapin populations, ultimately causing population declines.

Any terrapin small enough to fit through the crab pot funnel is capable of becoming trapped and subsequently drowning; however, due to their sexual dimorphism, adult males, as well as both sexes of young terrapins, are more vulnerable because they are smaller than adult females. Once captured, terrapins can drown within 45 to $300 \mathrm{~min}$ if access to oxygen is limited (Crowder et al. 2000). Selective removal of young terrapins of both sexes and adult males may cause shifts in population demography (e.g. sex ratios and age) that threaten the long-term viability of the population (Dorcas et al. 2007). Furthermore, considerable terrapin mortality can be attributed to abandoned or ghost pots (Bishop 1983, Roosenburg 1991, NCDENR DMF 2008, Grosse et al. 2009).

The seasonal distribution of both terrapins and crab fishing effort are of critical importance for assessing the potential for interactions. The activity and habitat use of diamondback terrapins are influenced by many dynamic factors, including tide, salinity, environmental temperatures, resource availability, reproduction, nesting, and predator avoidance. Based on the few existing studies, terrapins show a preference for low marsh and shallow water habitat. They exhibit limited home ranges (Roosenburg et al. 1999, Tucker et al. 2001, Sheridan et al. 2010) and strong site fidelity to tidal creeks, with occasional long distance movements (up to $12.5 \mathrm{~km}$ ) (Spivey 1998) associated with homing after being displaced or nesting (Hurd et al. 1979, Crowder et al. 2000, Gibbons et al. 2001, Butler 2002). However, these studies were restricted to the warmer months, when terrapins are most active, and lack detailed information on seasonal changes in terrapin activity patterns and habitat use at other times of the year (but see Butler 2002). Winter dormancy in this species has not been well-characterized, though we do know that it is correlated with latitude, and a decrease in water temperature $\left(6\right.$ to $\left.15^{\circ} \mathrm{C}\right)$ prompts terrapins to burrow in the inter- or subtidal mud and presumably remain inactive for extended time periods (Coker 1906, Yearicks et al. 1981, Butler 2002, Haramis et al. 2011).

The location of crab pots also varies seasonally and is driven by the movements and habitat use of blue crabs. Blue crabs inhabit shallow estuarine waters in the spring and summer months for reproductive needs and juvenile development, then move into deeper, more thermally stable waters in colder months (Mense \& Wenner 1989). Seasonal patterns in crab fishing can also be influenced by state regulations that may restrict or prohibit crab pot placement at certain times of the year (e.g. Maryland) (Roosenburg 2004).

An understanding of the extent and duration of spatial and temporal overlap between blue crab fisheries and terrapin habitat is essential for optimal management policies to protect terrapins. Previous studies have utilized the Williamson spatial overlap index (SOI) (Williamson 1993) to describe the degree to which the spatial correlation between fishing gear and a non-target bycatch species deviates from a random expectation under uniform spatial conditions (harbor porpoises: Cox 2003; sea turtles: Avissar et al. 2009, McClellan et al. 2009). In other words, the SOI predicts the overlap of fishing gear and bycatch species in a given landscape based on their distribution and density. An SOI of 1 represents uniform distribution of gear and bycatch species, an SOI > 1 represents a greater than expected gear-bycatch species overlap, and an SOI < 1 represents a lower than expected gear-bycatch species overlap.

We documented crab pot locations and monitored terrapin movements and activity patterns via radio telemetry within 2 estuarine sites in southeastern North Carolina over the course of 1 yr. We then used Williamson's SOI to determine the spatial overlap between terrapins and crab pots and generated a bycatch risk model to assess the potential for terrapin-crab pot interactions based on the SOI, density of crab pots, and a behavioral component, $\varphi$ (phi), to account for the pronounced seasonality of terrapin activity (Brennessel 2006, Southwood Williard \& Harden 2011). We hypothesized that terrapins and crab pots would be distributed in a manner that results in a high degree of overlap (SOI > 1) during the warm months when terrapins are active and a low degree of overlap (SOI < 1) during the winter when terrapins are presumably buried in the mud and dormant. Furthermore, we predicted a higher risk of bycatch during the active season.

\section{MATERIALS AND METHODS}

\section{Study sites}

The present study was conducted in estuarine waters surrounding 2 barrier islands along the southern portion of the North Carolina coast (Fig. 1). Terrapins were captured (see 'Field and radio telemetry') in small coves along the landward side of Masonboro Island (MAS; 34 $10^{\prime} 34^{\prime \prime} \mathrm{N}, 77^{\circ} 49^{\prime} 2^{\prime \prime} \mathrm{W}$ ) 


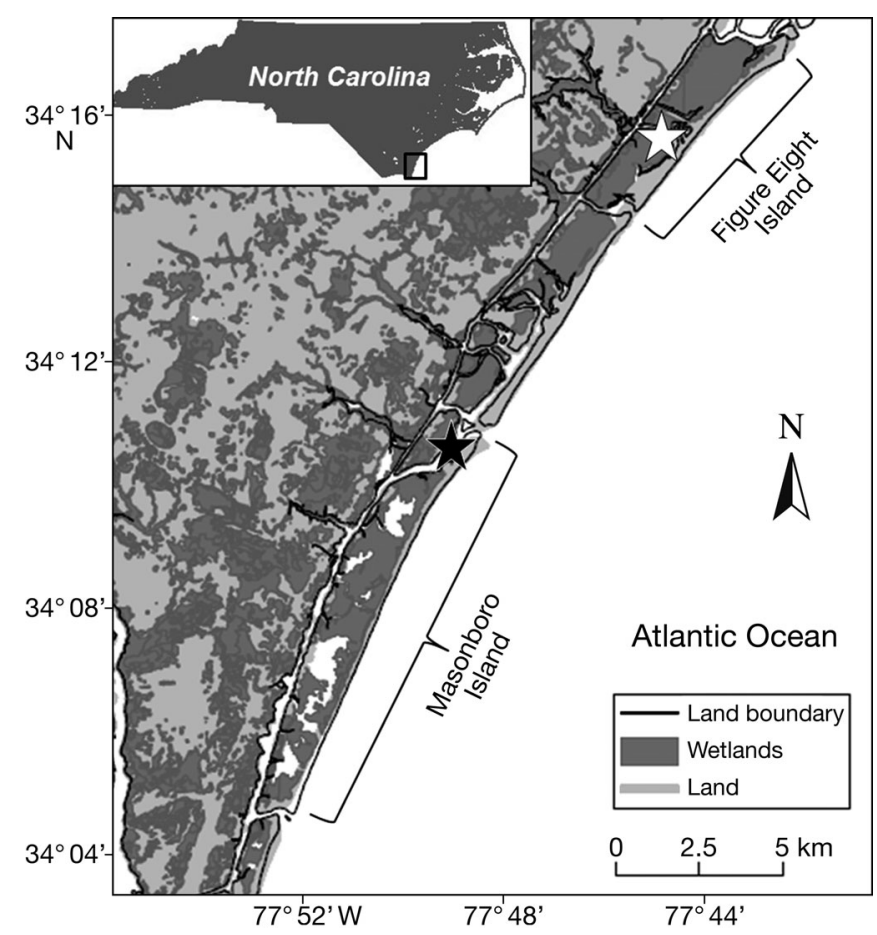

Fig. 1. Study sites on Figure Eight Island (F8) and Masonboro Island (MAS), barrier islands located along the southeastern coast of North Carolina. White star: F8 sampling site, black star: MAS sampling site

and Figure Eight Island (F8; $34^{\circ} 16^{\prime} 11^{\prime \prime} \mathrm{N}, 77^{\circ} 44^{\prime}$ $57^{\prime \prime} \mathrm{W}$ ) in tidally mixed areas with salinities ranging from 15 to 38 ppt. The MAS cove was relatively shallow (1.5 $\mathrm{m}$ at low tide) and surrounded by marsh and a deep channel ( 4 to $5 \mathrm{~m}$ ) frequently used by watercraft. The F8 cove was somewhat deeper (3 m at low tide) and surrounded by small, shallow tidal creeks ( 0 to $0.5 \mathrm{~m}$ at low tide) with patchy creekbank marsh habitat. Terrapin populations have been documented previously at both study sites, which are also frequently used by crab fishermen (local NC commercial crabbers, Division of Marine Fisheries, pers. comm.).

\section{Field and radio telemetry}

We used a $137 \mathrm{~m}$ gillnet with a mesh size of $3.2 \mathrm{~cm}$ to seine for terrapins at F8 and MAS from May to July 2008. Terrapins were each given a unique 3-letter code that was notched into the marginal scutes using a file (Sexton 1959). Terrapins were sexed, aged, and measured following processing protocols outlined by Dorcas et al. (2007). Radio transmitters were deployed on terrapins for which the combined mass of instruments and epoxy adhesive was $\leq 5 \%$ of terra- pin body mass. Of the 34 terrapins captured at F8, 15 were equipped with VHF radio transmitters, and of the 23 terrapins captured at MAS, 14 were equipped with VHF radio transmitters. Larger transmitters (PD2; Holohil Systems; $20 \mathrm{~mm} \times 10 \mathrm{~mm}, 250 \mathrm{~mm}$ antenna, 6 to $9.6 \mathrm{~g}, 10$ to $18 \mathrm{mo}$ life) with extended battery life were deployed on 22 large females and 1 large male (mean mass \pm standard deviation $[\mathrm{SD}]=573.2 \pm$ $133.7 \mathrm{~g}$ ), and smaller transmitters (SB-2; Holohil Systems; 4 g, 3 mo life) with a more limited battery life were deployed on 2 small females and 4 males (mean mass $\pm \mathrm{SD}=337.4 \pm 194.9 \mathrm{~g}$ ). Transmitters were attached to the anterior portion of the terrapin's carapace using quick-setting epoxy putty (Loctite ${ }^{\circledR}$ ).

Terrapins were radio-tracked 1 to 3 times per week from June 2008 to May 2009. Radio transmitter signals were detected using a VHF receiver (TR4 and TR-5, Telonics) and H-antennae (RA-2AK, Telonics). Efforts were made to visually locate terrapins for which VHF signals were detected. Upon relocation, Universal Transverse Mercator (UTM) coordinates of the terrapin's position were recorded using a hand-held global positioning system (GPS 72 Handheld Unit, $5 \mathrm{~m}$ accuracy, Garmin International), along with data regarding activity (e.g. swimming, at mud surface, or buried in mud), microhabitat (low marsh, high marsh, creekbank marsh, or tidal creek/cove), water depth, and tidal phase (low, mid, or high). Terrapin tracking was distributed across all tidal phases. Because the number of locations recorded for individual terrapins varied greatly at both sites (Table 1), terrapin locations were pooled together for each season at each site, and a minimum convex polygon (MCP) was used to calculate total range estimates (i.e. the entire area used by all tagged individuals) during the active season (ArcGIS 9.3 and Hawth's Tools Extension, ArcGIS, ESRI). We used Barrett's (1990) method to correct MCP home range areas for sample size bias by dividing the calculated area by $0.257 \ln (n)-0.31$, where $n$ is the number of observations used in the area calculation. This correction of MCP ranges allowed us to compare our terrapin home ranges with MCP home ranges calculated from other terrapin radio telemetry studies. Both sites were re-sampled in the summer of 2009 to recapture tagged terrapins and remove instruments.

\section{Model description}

We used a modified form of Williamson's spatially explicit predator-prey model (1993) to assess the 
Table 1. Morphometrics and radio telemetry data from diamondback terrapins captured at Figure Eight Island Cove $(\mathrm{F} 8, \mathrm{n}=$ 15) and Masonboro Island (MAS, $\mathrm{n}=14$ ) in 2008 and 2009. Sex was determined using protocols outlined by Dorcas et al. (2007). The number of signal detections refers to the number of times the receiver picked up a given radio frequency. The number of UTM locations refers to the number of times a terrapin was located by triangulation or visually. The number of visuals refers to the number of times the turtle was located visually where the UTM accuracy was $5 \mathrm{~m}$

\begin{tabular}{|lccccc|}
\hline Site & $\begin{array}{c}\text { No. of signal detections: } \\
\text { total (mean } \pm \text { SD) }\end{array}$ & $\begin{array}{c}\text { No. of UTM locations } \\
\text { recorded: total (mean } \pm \text { SD) }\end{array}$ & $\begin{array}{c}\text { No. of visuals: } \\
\text { total (mean } \pm \text { SD) }\end{array}$ & $\begin{array}{c}\text { Sex } \\
\text { Mass (g) } \\
\text { (mean } \pm \text { SD) }\end{array}$ \\
\hline F8 & $268(19 \pm 15)$ & $214(14 \pm 12)$ & $101(8 \pm 10)$ & $4 \mathrm{M}, 11 \mathrm{~F}$ & $337 \pm 195$ \\
MAS & $362(25 \pm 13)$ & $296(21 \pm 13)$ & $144(10 \pm 9)$ & $1 \mathrm{M}, 13 \mathrm{~F}$ & $573 \pm 133$ \\
\hline
\end{tabular}

overlap between terrapins and crab pots and the subsequent bycatch risk. The spatial overlap index, SOI, provides an indicator of the degree of overlap between crab pots and terrapins based on sample location $(z)$ and density of pots $(P)$ and terrapins $(N)$. Multiple sample locations may be assessed with the model, and $m$ represents the total number of locations. An SOI of 1 represents uniform distribution of predator and/or prey populations, an SOI $>1$ represents a greater than expected crab pot-terrapin overlap, with the upper limit determined by $m$, and an SOI $<1$ represents a lower than expected overlap, with a theoretical lower limit of 0 , meaning crab pots and terrapin co-occurred but did not overlap. The SOI is defined as:

$$
\mathrm{SOI}=\frac{\sum_{z=1}^{m}\left(P_{z} \times N_{z}\right) m}{\sum_{z=1}^{m}\left(P_{z}\right) \times \sum_{z=1}^{m}\left(N_{z}\right)}
$$

Once the SOI has been determined, the bycatch risk posed by a given density of crab pots on a given population of terrapins may be explored. To do this, we expanded on Williamson's (1993) concept of density risk (DR). In our study, DR was defined as the risk posed by an individual crab pot averaged over the whole population of terrapins and was a function of $P$ and the SOI. When crab pots and terrapins are uniformly distributed (i.e. $\mathrm{SOI}=1$ ), $\mathrm{DR}=P$, but when crab pot and terrapin populations are patchily distributed in space and/or time, $\mathrm{DR}=P \times \mathrm{SOI}$. We modified the equation for DR by introducing a new parameter $\varphi$ so that we could account for the strong seasonal shifts in terrapin behavior when assessing bycatch risk (BR):

$$
\mathrm{BR}=\mathrm{DR} \times \varphi
$$

$\varphi$ is a behavioral parameter that represents the probability that terrapins and crab pots are exhibiting the same 'behavior' that would allow them to interact. In this case, the behavior is being in water, and $\varphi$ was determined by the proportion of terrapin telemetry locations that were designated as 'swimming in open water' $(0<\varphi<1)$. Terrapins are semiaquatic and divide their time between muddy, exposed marsh habitats and open waters in the intertidal and subtidal zones (e.g. tidal creeks and channels). Blue crabs are fully aquatic; hence, crab pots are exclusively set in open waters in the intertidal and subtidal zones. Lower values for $\varphi$, indicative of terrapins spending more time in mud than in water, should decrease the BR even if the SOI and $P$ are high. Our model assumptions were that (1) our sample of terrapin distribution was representative of the terrapin population at F8 and MAS, (2) the observed distribution of crab pots was representative of the distribution of crabbing effort in these same areas, and (3) terrapin behaviors observed throughout this year-long study represent typical annual behaviors of terrapins.

\section{Model construction}

We used ArcInfo (ArcGIS 9.3, ESRI) to calculate probability density functions for terrapin and crab pot locations (i.e. point features) using a $100 \mathrm{~m}$ radius. This distance criterion was chosen to account for the maximum resolution (i.e. error estimate) of our data based on radio telemetry triangulations for terrapin locations (Cox 2003, McClellan et al. 2009). We then used ArcInfo to generate a $1200 \mathrm{~m} \times 1200 \mathrm{~m}$ grid for F8 and a $1500 \mathrm{~m} \times 1500 \mathrm{~m}$ grid of cells for MAS, which overlays the field site containing all turtle and crab pot UTM locations. The entire grid size selection was based on mean distance moved per tracking day, active season home range estimates, and maximum straight line distances recorded from both sites (see 'Results' for details). Each grid was made up of $100 \mathrm{~m} \times 100 \mathrm{~m}$ individual grid cells $\left(10000 \mathrm{~m}^{2}\right.$, or $1 \mathrm{ha}$, for each cell) that were determined based on the maximum 
resolution of our data, resulting in 144 grid cells for F8 and 225 grid cells for MAS.

$N$ and $P$ were calculated per season and per site. F8 $N$ was calculated using 193 active season and 21 dormant season UTM locations (total locations = 214; Table 1), and MAS $N$ was calculated using 222 active season and 74 dormant season UTM locations (total locations $=296$; Table 1). F8 $P$ was calculated using 38 active season and 22 dormant season UTM locations, and MAS $P$ was calculated using 22 active season and 25 dormant season UTM locations. Once $N$ and $P$ were determined, their combined density per individual 1 ha grid cell was calculated and used to determine the SOI of $N$ and $P$ per season per site using Eq. (1) above. Any grid cell that contained neither terrapin(s) nor crab pot(s) would be excluded because the SOI would automatically be 0 as a product of $N$ and $P$ being 0 . Finally, the BR for active and dormant season at each site was calculated using Eq. (2). All terrapin and crab pot locations were combined per season and per site for these calculations.

\section{Model evaluation}

We attempted to evaluate the performance of the model using our own observations of terrapin bycatch at F8, along with bycatch data from 2 experimental crab pots placed in F8 Cove from 2002 to 2005 by the North Carolina Department of Environment and Natural Resources and Division of Marine Fisheries (NCDENR DMF 2008). We used ArcGIS to plot locations of crab pots in which terrapin bycatch had been documented and then qualitatively evaluated the location of these pots in relation to areas of high terrapin-crab pot overlap.

To investigate the significance of our observed SOI values, we performed a bootstrap analysis (resample and replacement, 9999 iterations) in which we generated a random distribution of SOI values for each season at each site, with the observed SOI value being the 10000 th instance. We tested each observed SOI value (F8 active, F8 dormant, MAS active, and MAS dormant) against the null SOI of 1 using a $z$-test (SigmaPlot ver. 11.0, Systat Software), with which we compared the proportion of observations from the randomized SOI distribution with deviations from 1 that are greater than or equal to the corresponding observed SOI to the null proportion of 1 (significance at $\alpha \leq 0.05$ ). See Garrison et al. (2000) for more details on assessing the significance of spatial overlap index values.

\section{RESULTS}

\section{Field and radio telemetry}

Terrapins at F8 and MAS were radio-tracked from June 2008 to May 2009. The maximum straight line distance traveled from site of capture at F8 was $\sim 1050 \mathrm{~m}$ and at MAS was $\sim 1200 \mathrm{~m}$. There was a wide range in radio signal detections, recorded UTM locations, and visual observations per individual terrapin at both sites (Table 1), with fewer occurring in the dormant season. Sample size-corrected MCP total range sizes for the active season were smaller at MAS (25.8 ha, $\mathrm{n}=222)$ than F8 (52.9 ha, $\mathrm{n}=193)$.

In early October, when ambient water temperatures dropped and remained below $20^{\circ} \mathrm{C}$, terrapins exhibited a dramatic shift in behavior and activity by exiting the water column and burrowing to depths of 4 to $5 \mathrm{~cm}$ in creekbank and low marsh mud. Tagged terrapins were first documented as dormant (i.e. buried in mud in the same location for $>2 \mathrm{wk}$ ) between 3 October and 17 November 2008 at MAS (mud depth: $4.2 \pm 3.3 \mathrm{~cm}, \mathrm{n}=6$ ) and between 14 October and 4 December 2008 at F8 (mud depth: 4.5 $\pm 1.2 \mathrm{~cm}, \mathrm{n}=2$ ) in the low and creekbank intertidal marsh. During dormancy, we observed that turtles remained in the same location for up to $47 \mathrm{~d}$ at MAS $(37.2 \pm 8.1 \mathrm{~d})$ and $54 \mathrm{~d}$ at F8 $(44.0 \pm 14.1 \mathrm{~d})$. Terrapins were first documented emerging from dormancy (i.e. swimming) between 4 April and 22 May 2009 at MAS $(n=6)$ and on 17 April 2009 at F8 $(n=1)$. Based on our behavioral observations and telemetry results, location data was categorized into 1 of 2 seasons: the active season, which ran from April 1 to September 30 , and the dormant season, which ran from October 1 to March 31. We noted substantial seasonal differences in the behavior parameter, $\varphi$ : the proportion of total observations of terrapins swimming in subtidal water was greater in the active season than the dormant season at F8 $(\varphi=0.63$; Table 2$)$ and MAS $(\varphi=0.84$; Table 2$)$.

A total of 60 crab pots were recorded from June 2008 to May 2009 at F8, 38 of which were documented during the terrapin active season. Crab pots were typically located $\sim 15$ to $30 \mathrm{~m}$ from the wetland edge (i.e. emergent vegetation) and varied from 0.0 to $2.8 \mathrm{~m}$ deep at low tide with a mean water depth of $0.5 \mathrm{~m}$ in the active season and $1.2 \mathrm{~m}$ in the dormant season. From June 2008 to May 2009, we documented only 4 separate terrapin bycatch incidents. Three of the captured terrapins were still alive, and all of them were first time captures. A total of $47 \mathrm{crab}$ pots were recorded from July 2008 to June 2009 at 
Table 2. Seasonal changes in terrapin behavior based on visual observations derived from radio telemetry at Figure Eight Island (F8) and Masonboro Island (MAS). The behavior probability parameter, $\varphi$, takes into account the proportion of the observations that are accounted for by terrapin swimming behavior

\begin{tabular}{|lcccc|}
\hline \multirow{2}{*}{$\begin{array}{l}\text { Site/ } \\
\text { Season }\end{array}$} & $\mathrm{n}$ & \multicolumn{4}{c}{ Proportion of observations } \\
\cline { 5 - 5 } & & Swimming $(\varphi)$ & Mud surface & Buried \\
\hline F8 & & & & \\
Active & 193 & 0.63 & 0.17 & 0.2 \\
Dormant & 23 & 0.17 & 0.00 & 0.83 \\
MAS & & & & \\
Active & 266 & 0.84 & 0.15 & 0.01 \\
Dormant & 76 & 0.12 & 0.01 & 0.87 \\
\hline
\end{tabular}

MAS, 22 of which were documented in Masonboro Channel ( $\sim 3 \mathrm{~m}$ deep at low tide, $>50 \mathrm{~m}$ from wetland edge) during the terrapin active season with a mean water depth of $2.75 \mathrm{~m}$. Dormant season crab pots were placed much closer to the wetland edge in shallower water with a mean depth of $1.40 \mathrm{~m}$. No interactions between terrapins and crab pots were documented at MAS during our study.

\section{Spatial overlap index model}

Spatial overlap of crabbing effort and radiotracked terrapins occurred at both field sites during both the active and dormant seasons (F8: Fig. 2;
MAS: Fig. 3). The SOI revealed patchily distributed crab pot and terrapin populations $(\mathrm{SOI} \neq 1)$ that deviated from the expectation of uniform spatial co-distribution (Table 3 ). The active season SOI value was $>1$ at F8 $(\mathrm{SOI}=2.84)$ but not at MAS $(0.00)$. Contrary to our predictions, dormant season $\mathrm{SOI}$ values were $>1$ at MAS $(\mathrm{SOI}=1.62)$ and $\mathrm{F} 8(\mathrm{SOI}=2.97) . \mathrm{F} 8 \mathrm{SOI}$ values during both seasons were greater than MAS SOI values.

\section{Bycatch risk model}

DR was calculated for both seasons at both sites based on $P$ and SOI and then compared to BR, which accounted for the behavior of terrapins $(\varphi)$. When SOI $>1$, DR was always greater than $P$, indicating that a higher than expected overlap increases the chance of encounter between crab pots and terrapins. However, incorporation of $\varphi$ into the model resulted in BR values that were considerably lower than DR (Table 3), such that only the F8 active season BR was greater than $P$. In other words, the behavior of terrapins at F8 during the dormant season and at MAS during both the active and dormant season puts these animals at a decreased risk of bycatch, despite the fact that there is considerable overlap between terrapin habitat and crab pot placement. In our overall study, terrapins were at the highest risk for bycatch in crab pots at F8 during the active season (Table 3).
Island - Active Season

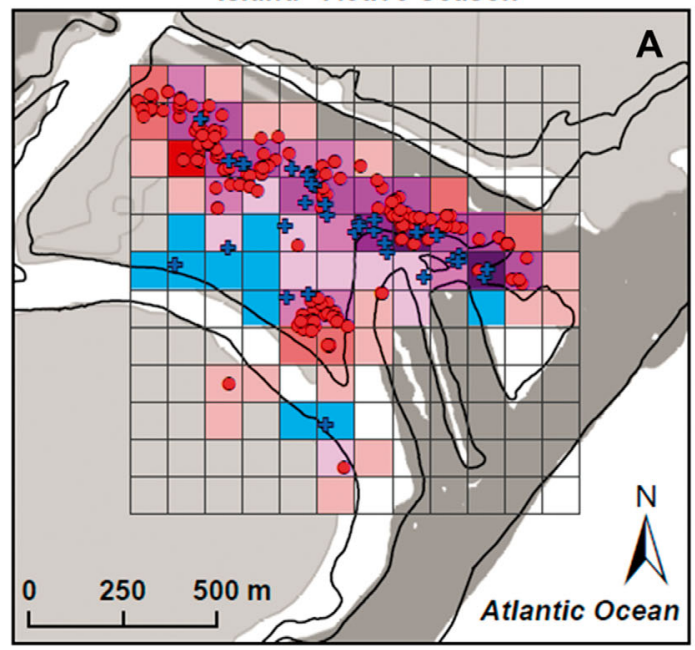

Island - Dormant Season

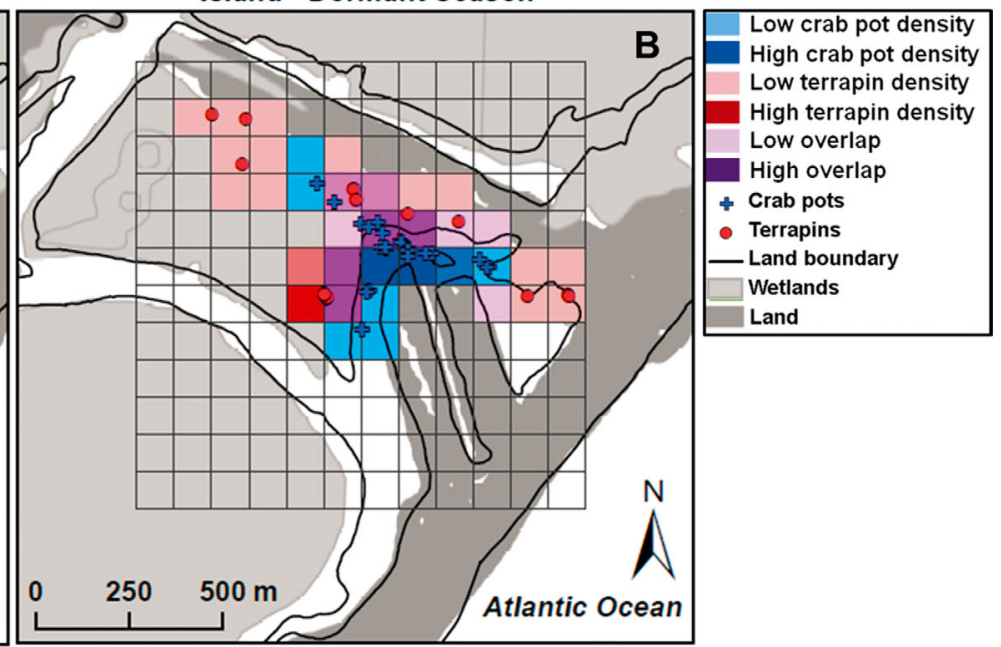

Fig. 2. Locations and density of terrapins and crab pots at Figure Eight Island (F8). Red circles are documented locations of individual terrapins, and blue crosses are documented locations of crab pots. Red shading of grid cells indicates relative terrapin density, blue shading indicates relative crab pot density, and purple indicates areas where relative terrapin and crab pot density overlap. Color gradation from light to dark represents relative density gradation from low to high. (A) Active season,

(B) dormant season 


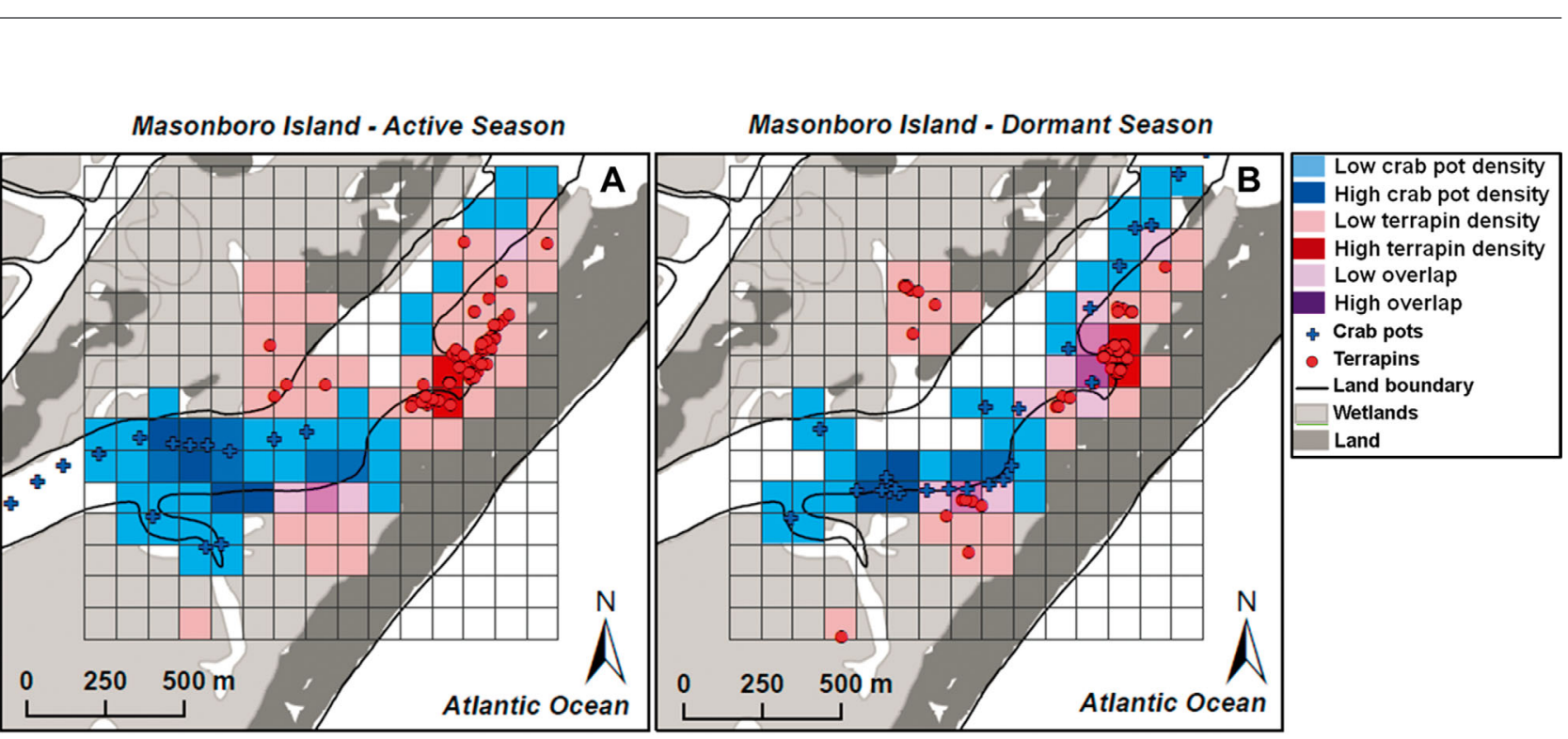

Fig. 3. Locations and density of terrapins and crab pots at Masonboro Island (MAS). See Fig. 2 for more detailed explanation of legend. (A) Active season, (B) dormant season

Table 3. Results of terrapin density $(N)$ and crab pot density $(P)$, terrapin bycatch, Williamson's spatial overlap index (SOI), density risk (DR), and bycatch risk (BR) based on seasonal behavior of terrapins (proportion swimming, $\varphi$ ) at Figure Eight and Masonboro Islands (F8 and MAS, respectively). Density values are per grid area (144 ha for F8; 225 ha for MAS)

\begin{tabular}{|c|c|c|c|c|c|c|c|}
\hline $\begin{array}{l}\text { Site/ } \\
\text { Season }\end{array}$ & $N$ & $P$ & SOI & $\begin{array}{c}\text { DR } \\
(P \times \mathrm{SOI})\end{array}$ & $\varphi$ & $\begin{array}{c}\mathrm{BR} \\
(\mathrm{DR} \times \varphi)\end{array}$ & $\begin{array}{l}\text { Terrapin } \\
\text { bycatch }\end{array}$ \\
\hline \multicolumn{8}{|l|}{ F8 } \\
\hline Active & 199.3 & 33.7 & $2.84^{\mathrm{a}}$ & $95.92^{\mathrm{b}}$ & 0.63 & $60.43^{c}$ & $4^{\mathrm{d}}$ \\
\hline Dormant & 20.7 & 20.7 & $2.97^{a}$ & $61.35^{\mathrm{b}}$ & 0.17 & 10.43 & 0 \\
\hline \multicolumn{8}{|l|}{ MAS } \\
\hline Active & 162.3 & 15.9 & 0.00 & 0.00 & 0.84 & 0.00 & 0 \\
\hline Dormant & 72.2 & 24.2 & $1.62^{\mathrm{a}}$ & $39.13^{b}$ & 0.12 & 4.69 & 0 \\
\hline \multicolumn{8}{|c|}{$\begin{array}{l}\text { aSOI }>1 \text { indicates patchy crab pot and terrapin distributions } \\
\text { that result in greater than expected spatial overlap. }{ }^{\mathrm{b}} \mathrm{DR}>P \\
\text { indicates that the patchy crab pot and terrapin distributions } \\
\text { increase DR. }{ }^{\mathrm{B}} \mathrm{BR}>P \text { indicates that the patchy crab pot } \\
\text { and terrapin distributions increase BR. }{ }^{\mathrm{d}} \text { Terrapins observed } \\
\text { caught in crab pots during this study, used as a model eva- } \\
\text { luation }\end{array}$} \\
\hline
\end{tabular}

\section{Model evaluation}

Documenting actual terrapin bycatch is difficult due to crabbing regulations that prohibit anyone other than the crabber from touching a marked crab pot. Therefore, we could only visually inspect shallowly placed crab pots at low tide when they were out of the water on dried creek bottom. As noted above, we documented 4 bycatch incidents in 4 separate crab pots at F8 during the active season: 2 in May (1 live female, 1 dead female), 1 in June (live female), and 1 in August (live female). When loca- tions for crab pots containing a terrapin were overlaid onto the F8 active season relative density data for terrapins and crab pots, these pots occurred within areas of moderate to high overlap (Fig. 4). Additionally, 2 crab pots placed in F8 Cove from April through September 2008 as part of a NCDENR DMF study captured 114 terrapins (107 dead) and also corresponded with areas of higher overlap (Fig. 4).

Bootstrap analyses indicated that the observed SOI values for both seasons at both sites were significantly different than the corresponding random distributions of SOI values $(\alpha<0.001$, Fig. 5). In other words, the spatial overlap of terrapins and crab pots deviates significantly from random expectation under uniform spatial distributions (i.e. the null hypothesis of SOI =1). The F8 active, F8 dormant, and MAS dormant seasons had observed SOI values that were significantly greater than that expected under uniform distribution, and the MAS active season had an observed SOI value that was significantly less than that expected under uniform distribution.

\section{DISCUSSION}

Our study is one of the first to document the spatial ecology of diamondback terrapins over the course of a year. Data describing seasonal changes in terrapin activity and habitat use are essential not only for identifying areas and times of increased terrapin bycatch risk but also for enhancing to our basic understanding of how these elusive reptiles interact 


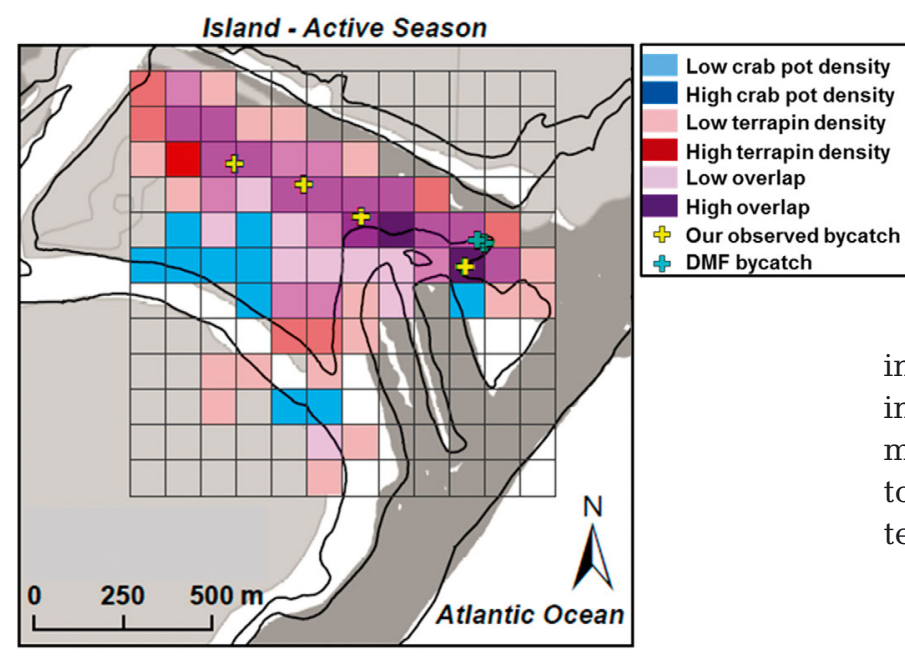

Fig. 4. Qualitative model evaluation using observed terrapin bycatch data (crab pots containing terrapins represented by yellow crosses) overlaid on Figure Eight Island active season relative density data for terrapins and crab pots (Fig. 2A). See Fig. 2 for more detailed explanation of legend. Crab pots with observed terrapin bycatch are located in areas of moderate to high relative terrapin and crab pot density overlap (medium to dark purple shade)

with their dynamic estuarine environment. Our sample size-corrected MCP total range sizes for terrapins during the active season at both sites indicate high site fidelity and short-distance movements that corroborate findings of other studies using aquatic sampling and molecular techniques (Roosenburg et al.

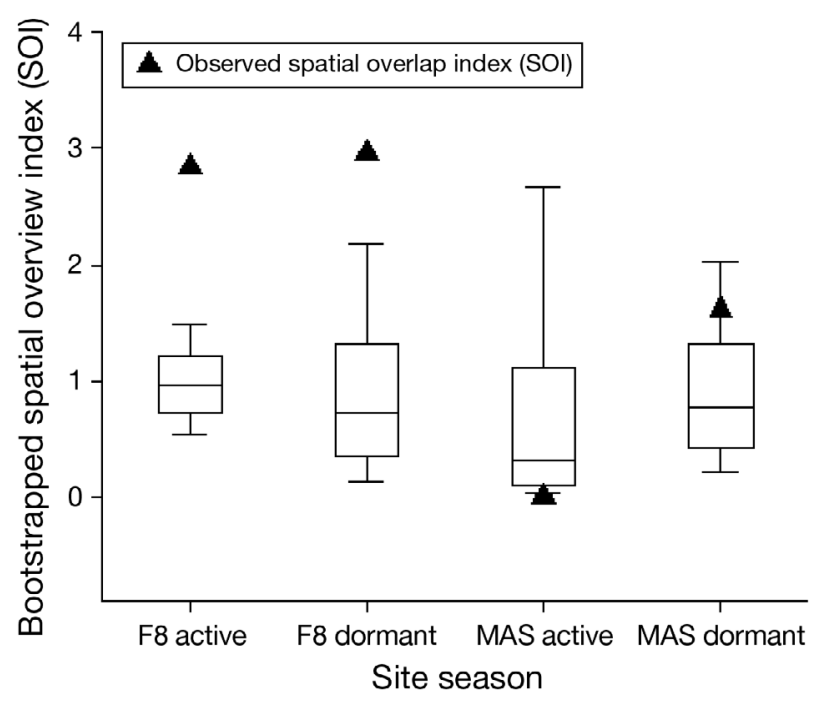

Fig. 5. Box plots characterizing distributions of SOI values generated from bootstrap resampling $(\mathrm{n}=9999)$. SOI values are grouped based on site and season. Each observed SOI value was tested against the null SOI of 1 using a $z$-test $(\alpha \leq 0.05)$. All observed SOI values were significantly different than the null SOI $(p<0.001)$
1999, Tucker et al. 2001, Sheridan et al. 2010). Total home ranges at MAS (25.8 ha) and F8 (52.9 ha) are comparable to mean MCP home range estimates for 8 female terrapins in North Florida (54.33 \pm 54.80 ha) (Butler 2002) but smaller than mean MCP home range estimates for 10 female terrapins in Bogue Sound, NC (305.4 $\pm 64.5 \mathrm{ha}$ ) (Spivey 1998). The differences in total ranges may be due to a variety of factors, including differences in habitat availability, nesting movements, radio transmitter range (Spivey 1998: 1.2 to $2.4 \mathrm{~km}$; our study: $1 \mathrm{~km}$ max.), and radio-tracking technique and frequency.

\section{Spatial and temporal overlap}

Our findings indicate that terrapins and crab pots co-occur and are patchily distributed in a manner that results in greater than expected overlap (SOI values > 1) for all study groups except for the MAS active season. Greater overlap at F8 than MAS corresponds to habitat differences between the 2 sites described earlier: F8 is surrounded by shallow tidal creeks and creekbank marsh, while MAS is surrounded by deeper channels. The low SOI value of 0.00 for the MAS active season denotes the co-occurrence but non-overlap of crab pots and terrapins and is a result of placement of crab pots in Masonboro Channel, which has water depths $>3 \mathrm{~m}$ and is $>50 \mathrm{~m}$ from shore. A low risk of bycatch at MAS during the active season is supported by previous studies, which documented a decrease in crab pot bycatch as distance from shore and water depth increases (Grant 1997, Hart \& Crowder 2011).

SOI values were high at F8 during both seasons, but there is a much higher risk of bycatch for terrapins during the spring and summer when activity levels are high (e.g. feeding and mating) and they spend a large proportion of their time in near-shore waters, according to previous crab pot and terrapin tracking studies (Grant 1997, Spivey 1998, Roosenburg et al. 1999, Crowder et al. 2000, Hart \& Crowder 2011). Early spring, in particular, may be a time of increased vulnerability for terrapins as many commercial crabbers set 'peeler pots' to capture molting female crabs in shallow-water habitat adjacent to marsh banks (Morris et al. 2011). Studies investigating the temporal and spatial magnitude of terrapin captures in commercial crab pots have found that terrapin bycatch is greatest in April and May (Bishop 1983, NCDENR DMF 2008, Hart \& Crowder 2011). Anecdotal data 
from North Carolina crabbers corroborate these findings of greater terrapin bycatch in spring ( $\mathrm{J}$. Wolfe \& J. Romano pers. comm.).

Although we can reject the null hypothesis that SOI $=1$, our results did not support our hypothesis that overlap would be less than expected $(<1)$ in the dormant season, suggesting that changes in seasonal crab pot distribution and density may be contributing to changes in overlap in addition to the seasonal ecology of the bycatch species. More specifically, these results could reflect that terrapins overwinter at sites other than their active foraging and mating sites and/or that crabs use different habitats in the dormant season and thus crabbers are responding accordingly by moving their pots. Additionally, crabbers who are aware of the decreased aquatic activity of terrapins in the winter months may move their pots into shallower, near-shore waters during this time of reduced bycatch risk (J. Wolfe, NC commercial crabber, pers. comm.). However, it is important to note that greater than expected dormant season overlap at MAS does not necessarily equate to greater bycatch risk due to the incorporation of aquatic activity of terrapins, $\varphi$, which is reduced during the winter. The addition of behavioral parameters can enhance spatially explicit models by extending their applicability to organisms with seasonal and/or semiaquatic habits.

Spatial overlap index values from our model are higher than values reported for marine mammal and sea turtle overlap with gill nets (Cox 2003, McClellan et al. 2009). This could be due to the temporal scale at which we combined our data, which was per season versus per month (Cox 2003) or per week (McClellan et al. 2009), or limitations on the amount of location data we could obtain using radio telemetry. All individuals of a population were grouped together rather than calculating separate density functions for each individual because we obtained far fewer locations using radio telemetry than is possible using satellite telemetry with larger marine vertebrates. Moreover, terrapins exhibit high site fidelity throughout their life, typically remaining in a small network of tidal creeks (Gibbons et al. 2001, Tucker et al. 2001, Sheridan et al. 2010) and moving an average of several hundred meters per tracking day (Harden et al. 2007, present study). Therefore, one might expect terrapins to have a greater spatial overlap with crab pots, which remain in a small area for weeks or months at a time, than the overlap between migratory species (e.g. sea turtles, porpoises, and sharks) and coastal nets.

\section{Qualitative model evaluation}

Identification of areas and times of high terrapin density that co-occur with blue crab fisheries allow for mapping of overlap and thus inferences of bycatch risk zones (Sims et al. 2008). High BR zones were defined as areas in which the possibility of terrapin-crab pot interactions is elevated due to (1) the increased seasonal aquatic behavior of terrapins and (2) the increased DR above that of $P$ caused by SOI > 1 (i.e. patchy and overlapping $N$ and $P$ ). Actual records of bycatch lend support the designation of bycatch risk zones. In our study, the high SOI and BR calculated for the F8 active season were corroborated by instances of terrapin bycatch in crab pots both during the course of our study as well as in previous studies (NCDENR DMF 2008). Using observed bycatch to qualitatively evaluate the performance of our model validates the SOI as a tool to identify high risk crabbing areas and predict interactions with terrapins. Previous studies have used the same SOI technique to assess bycatch risk of marine species in gill nets and have been successful in using the model to predict areas of actual bycatch occurrences with post hoc analyses (Cox 2003, McClellan et al. 2009). These studies were able to obtain all bycatch and stranding records from their field sites and therefore were able to better evaluate the performance of the model. For a quantitative model evaluation, we recommend applying this bycatch risk model to geographic areas where robust crab pot bycatch distribution data have been documented (e.g. York River, VA) (Rook et al. 2010, Morris et al. 2011).

\section{Broader applications}

Overall, the SOI was a useful tool in determining terrapin-crab pot overlap and identifying bycatch risk zones. The addition of the probability parameter $\varphi$ in the model allowed us to account for the semiaquatic behavior of terrapins and provided a more realistic estimate of bycatch risk than could be obtained by looking solely at distribution and density. Our study focused specifically on terrapin-crab pot interactions in North Carolina, but this approach could readily be used to identify bycatch risk zones in other areas of the terrapin's range where fisheries interactions are of concern (e.g. Chesapeake Bay, MD) (Roosenburg et al. 1997). Similar models have been used to identify multispecies bycatch risk zones on multiple scales in marine systems (Lewison et al. 2009) to inform fisheries management decisions 
(Sims et al. 2008). In the case of terrapins, distribution and density data collected by head-count surveys (Harden et al. 2009) or robust aquatic sampling over large regions (Grosse et al. 2011) can be combined with available data from the commercial fisheries to provide a broad scale assessment of terrapin-crab pot overlap. Integration of information on broad scale overlap with knowledge of regional terrapin ecology and crabbing practices could be used to identify bycatch risk zones and high priority fisheries management areas.

Bycatch risk models are valuable tools that may be used in conjunction with other mitigation measures to predict and prevent terrapin bycatch in crab pots. Models provide an attractive alternative to basing bycatch risk assessment solely on direct observations because (1) fisheries-reported bycatch data are not always reliable and consistent, and (2) experimental bycatch studies using modified crab pots may disturb or harm terrapins. Identification of bycatch risk zones allows fisheries managers to streamline their efforts to implement time- or area-based closures and permits targeted use of gear modifications, such as bycatch reduction devices, in the areas where terrapin encounters are most likely to occur. The use of modeling approaches along with other mitigation measures allows for better informed fisheries management decisions and augments efforts to reduce terrapin mortality.

Acknowledgements. We thank co-PI and fisherman J. Wolfe and UNCW undergraduates T. Burns and R. Myers for field assistance. S. Borrett, J. Will White, J. Halls, T. Cox, C. McClellan, S. Midway, and B. DeGregorio provided assistance with data analysis and comments to improve the manuscript. We thank S. Taylor of Division of Marine Fisheries for terrapin and fisheries-related expertise. We also thank D. Kellam of Figure Eight Island's Home Owner's Association for allowing vehicle access to our field site. UNCW Center for Marine Science watercraft personnel provided boating assistance. Funding was provided by North Carolina Sea Grant (BCSRP Project \#08-POP-06) and North Carolina Academy of Sciences Bryden Grant (2009). L.A.H. is supported by the National Science Foundation Graduate Research Fellowship. This research was approved by UNCW IACUC committee (protocols \#2008-005 and \#A1011-006), North Carolina Wildlife Resources Commission (Endangered Species Permit \# NC - 2008 ES 235 and 2011 ES 235), and the NC National Estuarine Research Reserve (\#112011).

\section{LITERATURE CITED}

Avissar NA, Hart KM, Crowder LB, Marsh J, Gannon J (2009) At loggerheads: evidence of loggerhead sea turtle damage to gear used in the blue crab (Callinectes sapidus) fishery. N Am J Fish Manag 29:163-169
Barrett SL (1990) Home range and habitat of the desert tortoise (Xerobates agassizi) in the Picacho Mountains of Arizona. Herpetologica 46:202-206

Bishop JM (1983) Incidental capture of diamondback terrapin by crab pots. Estuaries 6:426-430

Brennessel B (2006) Diamonds in the marsh: a natural history of the diamondback terrapin. University Press of New England, Lebanon, NH

Butler JA (2002) Population ecology, home range, and seasonal movements of the carolina diamondback terrapin, Malaclemys terrapin centrata, in Northeastern Florida. Final Report, Florida Fish and Wildlife Conservation Commission Tallahassee, FL

Coker RE (1906) The natural history and cultivation of the diamondback terrapin. Bull NC Geological Survey 14: $3-69$

Cox TM (2003) Evaluation of strategies to reduce bycatch of harbor porpoises (Phocoena phocoena). PhD dissertation, Duke University, Durham, NC

Crowder L, Hart K, Hooper M (2000) Trying to solve a bycatch and mortality problem: Can we exclude diamondback terrapins (Malaclemys terrapin) from crab pots without compromising blue crab (Callinectes sapidus) catch? Final Report, Marine Fisheries Commission, Sea Grant Fisheries Resource Grant 00-FEG-23. Durham, NC

Dorcas ME, Willson JD, Gibbons JW (2007) Crab trapping causes population decline and demographic changes in diamondback terrapins over two decades. Biol Conserv 137:334-340

Garrison LP, Michaels W, Link JS, Fogarty MJ (2000) Predation risk on larval gadids by pelagic fish in the Georges Bank ecosystem. I. Spatial overlap associated with hydrographic features. Can J Fish Aquat Sci 57: 2455-2469

Gibbons JW, Lovich JE, Tucker AD, Fitzsimmons NN, Greene JL (2001) Demographic and ecological factors affecting conservation and management of the diamondback terrapin (Malaclemys terrapin) in South Carolina. Chelonian Conserv Biol 4:66-74

Grant GS (1997) Impact of crab pot excluder devices on diamondback terrapin mortality and commercial crab catch. MS thesis, University of North Carolina Wilmington, Wilmington, NC

> Grosse AM, van Dijk JD, Holcomb KL, Maerz JC (2009) Diamondback terrapin mortality in crab pots in a Georgia tidal marsh. Chelonian Conserv Biol 8:98-100

> Grosse AM, Maerz JC, Hepinstall-Cymerman J, Dorcas ME (2011) Effects of roads and crabbing pressure on diamondback terrapin populations in coastal Georgia. J Wildl Manag 75:762-770

Haramis GM, Henry PF, Day DD (2011) Using scrape fishing to document terrapins in hibernacula in Chesapeak Bay. Herpetol Rev 42:170-177

Harden LA, DiLuzio NA, Dorcas ME, Gibbons JW (2007) The spatial ecology and thermal ecology of diamondback terrapins (Malaclemys terrapin) in a South Carolina salt marsh. J NC Acad Sci 123:154-162

> Harden LA, Pittman SE, Gibbons JW, Dorcas ME (2009) Development of a rapid assessment technique to monitor diamondback terrapin (Malaclemys terrapin) populations using head-count surveys. Appl Herpetol 6:237-245

$>$ Hart KM, Crowder LB (2011) Mitigating by-catch of diamondback terrapins in crab pots. J Wildl Manag 75: $264-272$ 
Hurd LE, Smedes G, Dean TA (1979) An ecological study of a natural population of diamondback terrapins (Malaclemys t. terrapin) in a Delaware salt marsh. Estuaries 2: 28-33

Lewison RL, Soykan CU, Franklin J (2009) Mapping the bycatch seascape: multispecies and multi-scale spatial patterns of fisheries bycatch. Ecol Appl 19:920-930

McClellan CM, Read AJ, Price BA, Cluse WM, Godfey MH (2009) Using telemetry to mitigate the bycatch of longlived marine vertebrates. Ecol Appl 19:1660-1671

Mense DJ, Wenner EL (1989) Distribution and abundance of early life history stages of the blue crab, Callinectes sapidus, in tidal marsh creeks near Charleston, South Carolina. Estuaries 12:157-168

Morris AS, Wilson SM, Dever EF, Chambers RM (2011) A test of bycatch reduction devices on commercial crab pots in a tidal marsh creek in Virginia. Estuaries Coasts 34:386-390

North Carolina Department of Environment and Natural Resources and Division of Marine Fisheries (2008) Access the effects of hurricanes on North Carolina's blue crab resource. NOAA Award Number NA16FW1543. Morehead City, NC

Rook MA, Lipcius RL, Bronner BM, Chambers RM (2010) Conservation of diamondback terrapin and catch of blue crab with a bycatch reduction device. Mar Ecol Prog Ser 409:171-179

Roosenburg WM (1991) The diamondback terrapin: population dynamics, habitat requirements and opportunities for conservation. New perspectives in the Chesapeake system: a research and management and partnership. Proceedings of a conference. Chesapeake Research Consortium Pub. No. 137. Chesapeake Research Consortium, Solomons, MD, p 234-237

Roosenburg WM (2004) The impact of crab pot fisheries on terrapin (Malaclemys terrapin) populations: Where are we and where do we need to go? In: Swarth C, Roosenburg WM, Kiviat E (eds) Conservation ecology of turtles of Mid-Atlantic Region - a symposium. Bibliomania, Salt Lake City, UT

Roosenburg WM, Cresko W, Modesitte M, Robbins MB (1997) Diamondback terrapin (Malaclemys terrapin) mortality in crab pots. Conserv Biol 11:1166-1172

Editorial responsibility: Romuald Lipcius, Gloucester Point, Virginia, USA
Roosenburg WM, Haley KL, McGuire S (1999) Habitat selection and movements of diamondback terrapins, Malaclemys terrapin, in a Maryland estuary. Chelonian Conserv Biol 3:425-429

Seigel RA, Gibbons JW (1995) Workshop on the ecology, status, and management of the diamondback terrapin (Malaclemys terrapin), Savannah River Ecology Laboratory, 2 August 1994: final results and recommendations. Chelonian Conserv Biol 1:240-243

> Sexton OJ (1959) Spatial and temporal movements of a population of the painted turtle, Chrysemys picta marginata (Agassiz). Ecol Monogr 29:113-140

Sheridan CM, Spotila JR, Bien WF, Avery HW (2010) Sexbiased dispersal and natal philopatry in the diamondback terrapin, Malaclemys terrapin. Mol Ecol 19: 5497-5510

Sims M, Cox T, Lewison R (2008) Identifying spatial patterns in fisheries bycatch: using models to improve the stability of bycatch estimates and aid fisheries management. Ecol Appl 18:649-661

Southwood Williard A, Harden LA (2011) Seasonal changes in thermal environment and metabolic enzyme activity in the diamondback terrapin (Malaclemys terrapin). Comp Biochem Physiol A Mol Integr Physiol 158: 477-484

Spivey PB (1998) Home range, habitat selection, and diet of the diamondback terrapin (Malaclemys terrapin) in a North Carolina estuary. MS thesis, University of Georgia, Athens, GA

Tucker AD, Gibbons JW, Greene JL (2001) Estimates of adult survival and migration for diamondback terrapins: conservation insight from local extirpation within a metapopulation. Can J Zool 79:2199-2209

Williamson CE (1993) Linking predation risk models with behavioral mechanisms: identifying population bottlenecks. Ecology 74:320-331

Wolak ME, Gilchrist GW, Ruzicka VA, Nally DM, Chambers RM (2010) A contemporary, sex-limited change in body size of an estuarine turtle in response to commercial fishing. Conserv Biol 24:1268-1277

Yearicks EF, Wood CR, Johnson WS (1981) Hibernation of the Northern diamondback terrapin, Malaclemys terrapin terrapin. Estuaries 4:78-81

Submitted: March 5, 2012; Accepted: July 24, 2012 Proofs received from author(s): October 16, 2012 